ISSN 1392-3196 / e-ISSN 2335-8947

Zemdirbyste-Agriculture, vol. 103, No. 2 (2016), p. 167-174

DOI 10.13080/z-a.2016.103.022

\title{
Efficacy of fungicides in sugar beet crops
}

\author{
Dovilè AVIŽIENYTÉ ${ }^{1}$, Zita BRAZIENE' ${ }^{1}$, Kęstutis ROMANECKAS ${ }^{2,3}$, \\ Antanas MARCINKEVIČIUS ${ }^{1}$ \\ ${ }^{1}$ Rumokai Experimental Station, Lithuanian Research Centre for Agriculture and Forestry \\ Klausučiai, Vilkaviškis distr., Lithuania \\ E-mail: rumokai@lammcrumokai.lt \\ ${ }^{2}$ Aleksandras Stulginskis University \\ Studentų 11, Akademija, Kaunas distr., Lithuania \\ E-mail: kestas.romaneckas@asu.lt \\ ${ }^{3}$ Kaunas Forestry and Environmental Engineering College \\ Liepų 1, Girionys, Kaunas distr., Lithuania
}

\begin{abstract}
Cercospora and ramularia leaf spot are the most damaging fungal diseases of sugar beet in Europe. The aim of the current study was to evaluate the severity of fungal diseases and the efficacy of various fungicides and their doses in sugar beet crops in Lithuania. A short-term field experiment was carried out in 2012 and 2013 at Rumokai Experimental Station, Lithuanian Research Centre for Agriculture and Forestry on a moderately heavy loam HapliEpihypogleyic Luvisol ( $L V g-p-w-h a)$. Fungicides Impact (a.i. flutriafol), Opus (a.i. epoxiconazole), Artea (a.i. propikonazole + cyproconazole), Folicur (a.i. tebuconazole), Opera N (a.i. pyraclostrobin + epoxiconazole) were applied as a single application at the beginning of the disease occurrence (in August) and as a double application, with one spray at the beginning of the disease occurrence (in August) plus a second spray one month later (in September).

The experimental results showed that the main fungal diseases in the sugar beet crops tested were Cercospora beticola and Ramularia beticola. Erysiphe betae was of minor severity. The application of fungicides significantly decreased the severity of cercospora and ramularia leaf spots by on average $19.8-81.8 \%$ and $71.8-91.8 \%$, respectively. The most effective fungicides were Opus (a.i. epoxiconazole) and Impact (a.i. flutriafol). A single or double application of all the investigated fungicides had essentially the same effect. The most effective against powdery mildew was fungicide Opus, treated twice.

Various active ingredients of the fungicides had insignificant effect on sugar beet yield and sucrose content in the roots. A single application of the fungicide Artea $0.5 \mathrm{~L} \mathrm{ha}^{-1}$ (a.i. propiconazole + cyproconazole) and a double application Opus 1.0 L ha-1 (a.i. epoxiconazole) and Folicur $1.0 \mathrm{~L} \mathrm{ha}^{-1}$ (a.i. tebuconazole) significantly decreased the content of impurities (potassium, sodium, alpha amino nitrogen) in the sugar beet roots compared with the untreated control treatment.
\end{abstract}

Key words: Beta vulgaris, Cercospora beticola, Erysiphe betae, quality, Ramularia beticola, yield.

\section{Introduction}

The productivity of crops mainly depends on the intensity of photosynthesis; therefore, it is so important to keep leaves healthy. Recently, cercospora leaf spot (Cercospora beticola Sacc.) and ramularia leaf spot (Ramularia beticola Fautrey \& F. Lamb.) have become the most widespread and damaging fungal diseases of sugar beet in Lithuania (Gaurilčikienè et al., 2006). Weiland and Koch (2004) have highlighted the same problem in many other countries. According to Hanse et al. (2011), despite crop protection, sugar beet yield losses due to pests and diseases for the best growers amounted to $30.2 \%$ and $13.1 \%$ and on average $37.1 \%$ and $16.7 \%$ on sandy and clay soils, respectively.

Cercospora damages leaves. In both sides of a leaf a pathogen forms little spots. Spots are circular, about 3 to $5 \mathrm{~mm}$ in diameter, with light to dark tan centres and dark-brown to reddish-purple borders. Cercospora spores form most rapidly at $20-26^{\circ} \mathrm{C}$ and a relative humidity of $90-100 \%$. Spores germinate and infect leaves at daytime temperatures of $25-35^{\circ} \mathrm{C}$, night temperatures above $15^{\circ} \mathrm{C}$, and high relative humidity $(90-95 \%)$ or free moisture. Leaf spots develop from 5 to 21 days after infection, depending on the sum of active temperatures and duration of wet period. Cercospora firstly damages old leaves of sugar beet and disperses on young ones later (Compendium..., 1986). In Lithuania, first symptoms of the disease emerge in July and result in a higher proportion of alpha amino nitrogen and lower sucrose content in the roots of sugar beet (Petkevičienè, Kaunas, 2004). Vereijssen et al. (2003) indicated that 
cercospora leaf spot in sugar beet may cause reduction of $42 \%$ gross sugar yield through root weight and sugar content decrease. Hoffmann et al. (2009) have reported that research data from 2 field experiments out of 55 were not presented due to severe infestation of Cercospora beticola. According to Khan (2015), during the past 15 years in Minnesota and North Dakota, crop rotation and combinations of different fungicides have decreased cercospora leaf spot infestation. This led to the reduction in the number of fungicide applications, and savings compounded about 14 million US dollars annually compared to the last epidemic in 1998.

Ramularia pathogen attacks older leaves. Lesions mainly have a dark brown to reddish brown margin. Centres are silver grey to white (Duffus, Ruppel, 1993). Ramularia leaf spot develops in colder weather; optimal temperature is $17^{\circ} \mathrm{C}$, relative humidity higher than 95\% (Asher, Hanson, 2006). In Lithuania, ramularia leaf spot emerges at the beginning of August. In some years, this disease disperses widely, sugar beet leaves dry-out, sugar beet root yield and sugar yield drastically decrease (Žemès ūkio augalu kenkejjai..., 2002). Thach et al. (2013) concluded that Ramularia beticola in sugar beet was a serious disease in 5 out of 11 seasons. The severity and significance of the disease varied depending on the rainfall rate, particularly in two specific weeks in July and September.

Powdery mildew (Erysiphe betae Vanha, Weltzien) disperses during long periods of dry weather with warm days and cold nights. The variation between day and night temperatures is high, and dew forms on the plants (Žemès ūkio augalų kenkèjai..., 2002). Powdery mildew severity increases with the age of plants, i.e. at the end of sugar beet vegetation (Duffus, Ruppel, 1993). This pathogenic fungal disease can decrease root yield by up to $30 \%$ (Francis, 2002).

A suitable pre-crop, early sowing and resistant sugar beet varieties are the main natural ways to control the spread of fungal diseases (Piszczek, 2001). However, yield decrease of the investigated resistant varieties grown in Cercospora-free environments was $5-7 \%$ (Gummert et al., 2015). The application of synthetic fungicides is stills the most effective disease control method. It is very important to choose the right fungicides, their application doses and timing. Fungicides are the most effective at the beginning of disease emergence so we need to apply the right disease diagnostics methods, precise evaluation of meteorological conditions and plant growth stages. For the prevention of plant pathogens resistance to the fungicide used, it is recommended to use products containing different active ingredients (Secor et al., 2010; Baltaduonyte et al., 2013). The objectives of our investigations were: 1) to evaluate the severity of fungal diseases; 2) to establish the efficacy of various active ingredients of fungicides, their application timing and doses on the severity of the main fungal diseases in the sugar beet crops; 3 ) to evaluate sugar beet yield and quality of roots.

\section{Materials and methods}

A short-term field experiment was carried out in 2012 and 2013 at Rumokai Experimental Station, Lithuanian Research Centre for Agriculture and Forestry on a moderately heavy loam Hapli-Epihypogleyic Luvisol $(L V g-p-w-h a)(\mathrm{WRB}, 2014)$. The chemical composition of the soil arable layer is presented in Table 1.

Table 1. Average soil chemical composition of the experimental fields in 2012 and 2013

\begin{tabular}{cccc}
\hline Index & Dimension & 2012 & 2013 \\
\hline $\mathrm{pH}$ & $\mathrm{mol} \mathrm{KCl} \mathrm{dcm}^{-3}$ & 6.7 & 6.6 \\
Available $\mathrm{P}_{2} \mathrm{O}_{5}$ & $\mathrm{mg} \mathrm{kg}^{-1}$ & 284 & 367 \\
Available $\mathrm{K}_{2} \mathrm{O}$ & $\mathrm{mg} \mathrm{kg}^{-1}$ & 252 & 308 \\
humus & $\mathrm{g} \mathrm{kg}^{-1}$ & 17.8 & 17.3 \\
$\mathrm{~N}_{\text {total }}$ & $\mathrm{g} \mathrm{kg}^{-1}$ & 1.5 & 1.3 \\
\hline
\end{tabular}

Treatments of the experiment are described in Table 2. The fungicides were applied in August and September after disease severity tests. A hand-operated sprayer Hardi BP-15 (HardiSprayer, RAJ and Associates, LLC, USA) was used, water volume $-300 \mathrm{~L} \mathrm{ha}^{-1}$.

Table 2. Application timing and doses of fungicides

\begin{tabular}{|c|c|c|c|c|c|}
\hline \multirow{2}{*}{ No. } & \multirow{2}{*}{ Fungicide } & \multirow{2}{*}{$\begin{array}{l}\text { Dose } \\
\text { L ha }^{-1}\end{array}$} & \multirow{2}{*}{$\begin{array}{c}\text { Fungicide } \\
\text { a.i. }\end{array}$} & \multicolumn{2}{|c|}{ Dose $\mathrm{g} \mathrm{ha}^{-1}$ a.i. / application } \\
\hline & & & & $1^{\text {st }}$ & $2^{\text {nd }}$ \\
\hline 1. & Untreated (control) & - & - & - & - \\
\hline 2. & Impact & 0.4 & flutriafol & 100 & - \\
\hline 3 . & Opus & 1.0 & epoxiconazole & 125 & - \\
\hline 4. & Artea & 0.5 & propiconazole + cyproconazole & $125+40$ & - \\
\hline 5. & Folicur & 1.0 & tebuconazole & 125 & - \\
\hline 6. & Opera $\mathrm{N}$ & 0.8 & pyraclostrobin + epoxiconazole & $68+50$ & - \\
\hline 7. & Impact & $0.25 \times 2$ & flutriafol & 62.5 & 62.5 \\
\hline 8. & Opus & $1.0 \times 2$ & epoxiconazole & 125 & 125 \\
\hline 9. & Artea & $0.5 \times 2$ & propiconazole + cyproconazole & $125+40$ & $125+40$ \\
\hline 10. & Folicur & $1.0 \times 2$ & tebuconazole & 125 & 125 \\
\hline 11. & Opera $\mathrm{N}$ & $0.8 \times 2$ & pyraclostrobin + epoxiconazole & $68+50$ & $68+50$ \\
\hline
\end{tabular}

The gross size of each experimental plot was $32.4 \mathrm{~m}^{2}$, net size $-13.5 \mathrm{~m}^{2}$. The experiment was carried out in four replications. The randomized block design was used.

The pre-crop of sugar beet was spring wheat. In spring, mineral fertilizer NPK 12-11-22 was incorporated into the soil during cultivation at 780 (2012) and 660 (2013) $\mathrm{kg} \mathrm{ha}^{-1}$ rates. Sugar beet crop was fertilized additionally with ammonium nitrate at 150 (2012) and 202 (2013) $\mathrm{kg} \mathrm{ha}^{-1}$ rates and Tradebor $-1.5 \mathrm{~L} \mathrm{ha}^{-1}$. Sugar beet varieties 'Ernestina' (2012) and 'Hestia' (2013) were grown in the experimental plots. The sowing rate was 138888 seeds per hectare, distance between rows $0.45 \mathrm{~m}$, between seeds $-0.16 \mathrm{~m}$.

To control weeds and pests in sugar beet crops, we followed Deveikyte et al. (2009) recommendations. 
In 2012, two herbicide applications were used: Betanal Expert $\left(1.25 \mathrm{~L} \mathrm{ha}^{-1}\right)+$ Goltix $\left(1.00 \mathrm{~L} \mathrm{ha}^{-1}\right)$, Betanal Expert $\left(1.30 \mathrm{~L} \mathrm{ha}^{-1}\right)+$ Caribou $\left(0.015 \mathrm{~kg} \mathrm{ha}^{-1}\right)$. In 2013, the herbicides were applied three times: Contact $\left(0.6 \mathrm{~L} \mathrm{ha}^{-1}\right)$ + Ethosat $\left(0.3 \mathrm{~L} \mathrm{ha}^{-1}\right)+$ Goltix $\left(1.0 \mathrm{~L} \mathrm{ha}^{-1}\right)+$ Poweroil (vegetable oil, $\left.0.5 \mathrm{~L} \mathrm{ha}^{-1}\right)$, Agil (1.5 $\left.\mathrm{L} \mathrm{ha}^{-1}\right)$, Betanal MaxxPro (1.4 $\left.\mathrm{L} \mathrm{ha}^{-1}\right)+$ Caribou $\left(0.015 \mathrm{~kg} \mathrm{ha}^{-1}\right)$. Insecticide Proteus $\left(0.75 \mathrm{~L} \mathrm{ha}^{-1}\right)$ was applied only in 2013 .

Assessments of the disease severity were done three times on the $1^{\text {st }}$ of August (before fungicide application), on the $1^{\text {st }}$ of September (a month after the first fungicide application) and on the $1^{\text {st }}$ of October (a month after the second fungicide application). Disease severity was estimated by establishing the diseaseaffected leaf area in per cent according to the scale: 0 , 1, 2, 5, 10, 25, 35, 45 and 60 (EPPO Standards, 2004; Baltaduonyte et al., 2013). The disease severity (R) was calculated according to the formula:

$$
\mathrm{R}=\frac{\sum(\mathrm{n} \times \mathrm{b})}{\mathrm{N}}
$$

where $\mathrm{n}$ is number of leaves with the same grade or percentage of damage, $\mathrm{b}$ - damage value, $\mathrm{N}$ - number of tested leaves.

The biological efficacy of the fungicides $(\mathrm{X})$ was evaluated according to the results of the last disease severity test:

$$
\mathrm{X}=\frac{\mathrm{a}-\mathrm{b}}{\mathrm{a}},
$$

where a is disease severity in the control treatment, $\mathrm{b}$ - disease severity in the fungicide applied treatment (Baltaduonyte et al., 2013).
Roots for sugar beet productivity and quality tests were selected in the second ten-day period of October. Sugar beet root quality analyses were performed at the laboratory of the joint-stock company "Nordic Sugar Kèdainiai”.

ANOVA was applied for data statistical evaluation. The treatment effect was tested by the least significant differences $\mathrm{LSD}_{05}, \mathrm{LSD}_{01}$ and $\mathrm{P}$ tests by software SigmaStat. If $P \leq 0.050>0.010$, the differences from the control treatment are significant at $95 \%$ probability level; if $P \leq 0.010$ - at $99 \%$ probability level and if $P>0.050$, there is no significant difference.

The weather conditions during the 2012 and 2013 sugar beet growing seasons are presented in Figure. In 2012, spring was late but warm. In April, a daily average temperature was $7.9^{\circ} \mathrm{C}$ or by $1.8^{\circ} \mathrm{C}$ higher than the long-term average. Precipitation rate was $54.3 \mathrm{~mm}$ or by $14.3 \mathrm{~mm}$ higher than usual. So, the conditions for sugar beet germination were favourable. The weather in May was warmer and dryer than usual. Average air temperature was by $1.5^{\circ} \mathrm{C}$ higher and precipitation rate by $8.6 \mathrm{~mm}$ less than the long-term average. Unlike in May, June was slightly colder and by about $30 \%$ more humid. July was in abundance of moisture too, but the average temperature was by $1.7^{\circ} \mathrm{C}$ higher than usual. August was extremely by about $50 \%$ dryer than usual.

The weather conditions in September were similar to long-term average. In October, average air temperature was $8.3^{\circ} \mathrm{C}$ or by $1.3^{\circ} \mathrm{C}$ higher than usual. In Denmark Thach et al. (2013) found that the severity of the diseases strongly depended on the increase of
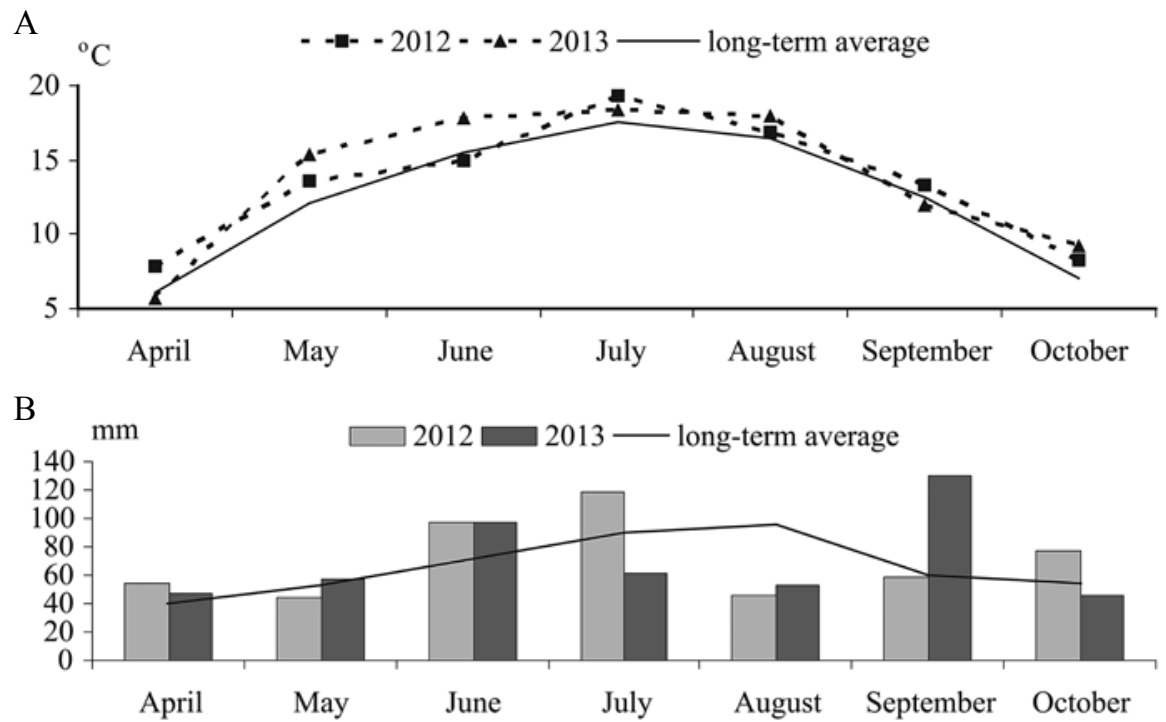

Figure. Average air temperature (A) and precipitation rate (B) during sugar beet growing season (Kybartai Meteorological Station)

precipitation rates in the periods between May and September (weeks 18-39). In our experiment, in the period between June and July 2012, precipitation rate was surplus, but between August and September - deficient. Contrary to Thach et al. (2013) findings, we established strong negative correlation between precipitation rate and ramularia leaf spot severity $\left(r=-0.715^{*}\right)$ in the period between June and September (11 weeks). Increase of sum of active temperatures did not correlate with the incidence of cercospora and ramularia, but was favourable for powdery mildew severity $(r=0.423)$. We found the relationship between solar radiation rate and severity of cercospora $(r=0.499)$ and powdery mildew $\left(r=0.675^{*}\right)$.

The April of 2013 was slightly colder and more humid than usual. In May, average air temperature was by $3.3^{\circ} \mathrm{C}$ higher and with $4.5 \mathrm{~mm}$ higher precipitation rate than long-term average. June showed similar tendencies as in May; however, precipitation rate was by about $27 \%$ higher than usual. Conversely, in July precipitation rate was nearly twice less than long-term average. Similar weather was observed in August too. These conditions 
were not favourable for rapid emergence of fungal diseases. We found negative relationship between severity of sugar beet diseases and average air temperature or precipitation rate and sum of active temperatures in the period between June and September. September was humid; precipitation rate was more than twice higher than usual. In October, the weather conditions were warmer and drier and were conducive to sucrose assimilation.

\section{Results and discussion}

Cercospora leaf spot. The most widespread fungal diseases in the experiment were cercospora leaf spot and ramularia leaf spot. In each year, incidence of powdery mildew was low and beet rust (Uromyces betae) - unusual. Beet rust is mainly of minor importance (Märländer et al., 2003).

In our experiment, in 2012 and 2013 before fungicide application (first assessment of diseases), the severity of cercospora was low $-0.02-0.21 \%$. In 2012 , a month after the first application of fungicides, the severity of cercospora leaf spot increased (Table 3). Assessment of the disease severity showed that a single application of fungicides decreased disease severity significantly by 2-16 times compared to the untreated plots. The most effective was application of Opera N $0.8 \mathrm{~L} \mathrm{ha}^{-1}$ (treatment No. 6).

A month after the second application of fungicides, in the control plots, disease severity increased about three times. Correlation analysis showed strong relationship between severities of the second (a month after the first fungicide application) and the third (a month after the second fungicide application) sugar beet assessments $(r=$ $\left.0.914^{*}\right)$. This means that the incidence of cercospora leaf spot continued to increase because of the eighteen rainy days, especially $7^{\text {th }}, 13^{\text {th }}$ and $23^{\text {th }}$ September with $7.4,5.8$ and $21.1 \mathrm{~mm}$ precipitation rates.

During the month after the second fungicide application, the lowest severity of cercospora disease $(1.70 \%)$ was observed in the plots treated with Opus $1 \mathrm{~L} \mathrm{ha}^{-1}$ twice (treatment No. 8). However, the difference between single and double application of fungicide Opus was insignificant. This can be said about the other treatments too, except Artea. A double application of Artea significantly (about 2.5 times) decreased the severity of cercospora compared with a single application. Baltaduonyte and Dabkevičius (2015) reported that the highest incidence was of cercospora leaf spot, whose severity varied from $1.73 \%$ to $16.71 \%$; ramularia leaf spot severity ranged from $0.23 \%$ to $1.83 \%$. Vereijssen et al. (2007) established that active ingredient difenoconazole $\left(250 \mathrm{~g} \mathrm{~L}^{-1}\right)$ reduced cercospora severity by up to $50 \%$ and resulted in significantly higher relative sugar yields than those in the unsprayed plots.

As in 2012, in 2013 at the time of the second assessment of the disease severity, the incidence of cercospora leaf spot increased drastically, especially in the untreated plots (Table 3). The first fungicide application significantly decreased the severity of cercospora, except in the plots treated with $1 \mathrm{~L} \mathrm{ha}^{-1}$ Folicur. In a month after the second fungicide application, disease severity in the untreated plots naturally increased about twice. As in 2012, the correlation analysis highlighted strong relationship between severities during the month (September) between the second and the third evaluations $\left(r=0.817^{* *}\right)$ because it rained for 22 days in September, and the precipitation rate was by $69 \mathrm{~mm}$ higher (nearly twice) than usual.

The second application of fungicides was less effective than the first. Half of the treatments (Nos. 3, 5, 9, 10 and 11) showed insignificant results (Table 3). Generally, double application of fungicides was insignificant compared to single. The efficacy of fungicides at the end of sugar beet growing season could be lower because cercospora damaged more leaves.

The biological efficacy of fungicide application is the indicator showing how much (in \%) disease severity changes after sprayings. In all cases, fungicide application in sugar beet crop was effective against cercospora leaf spot (Table 4). In 2012, the most effective was fungicide Opus (treatments No. 3 and 8), and in 2013 - single application of Artea and double - Impact (treatment Nos. 4 and 7).

Generally, application of the fungicide Opus once or twice (a.i. epoxiconazole) and Impact (a.i. flutriafol) twice was the most effective against cercospora leaf spot. Like in our investigations, Trkulja et al. (2015) found that the tested multiple demethylation-inhibiting fungicides Impact, Opus and other (a.i. flutriafol, epoxiconazole, epoxiconazole + carbendazim, thiophanate-methyl + epoxiconazole and flutriafol + chlorothalonil) applications effectively controlled the cercospora leaf spot in sugar beet crop.

Ramularia leaf spot. At the time of the first disease assessment, the ramularia severity in sugar beet crop was weak (data are not presented). In 2012, a month after the first application of fungicides (the second

Table 3. Cercospora leaf spot severity (\%) in sugar beets crops

\begin{tabular}{|c|c|c|c|c|c|c|c|}
\hline \multirow[t]{2}{*}{ No. } & \multirow[t]{2}{*}{ Treatment } & \multicolumn{2}{|c|}{$\begin{array}{l}\text { Before fungicide } \\
\text { application }\end{array}$} & \multicolumn{2}{|c|}{$\begin{array}{l}\text { A month after the first } \\
\text { fungicide application }\end{array}$} & \multicolumn{2}{|c|}{$\begin{array}{l}\text { A month after the second } \\
\text { fungicide application }\end{array}$} \\
\hline & & 2012 & 2013 & 2012 & 2013 & 2012 & 2013 \\
\hline 1. & Untreated (control) & $0.05 \mathrm{a}$ & $0.18 \mathrm{a}$ & $6.82 \mathrm{a}$ & $6.00 \mathrm{a}$ & $21.32 \mathrm{a}$ & $10.95 \mathrm{a}$ \\
\hline 2. & Impact $0.4 \mathrm{~L} \mathrm{ha}^{-1}$ & $0.02 \mathrm{a}$ & $0.05 \mathrm{a}$ & $0.80 \mathrm{~d}^{* *}$ & $0.75 b^{* *}$ & $4.88 \mathrm{~d}^{* *}$ & $4.35 \mathrm{bc}^{*}$ \\
\hline 3. & Opus $1.0 \mathrm{~L} \mathrm{ha}^{-1}$ & $0.02 \mathrm{a}$ & $0.05 \mathrm{a}$ & $1.00 \mathrm{~cd}^{* *}$ & $1.75 b^{* *}$ & $2.68 \mathrm{~d}^{* *}$ & $5.90 \mathrm{abc}$ \\
\hline 4. & Artea $0.5 \mathrm{~L} \mathrm{ha}^{-1}$ & $0.08 \mathrm{a}$ & $0.00 \mathrm{a}$ & $1.98 \mathrm{bcd}^{* *}$ & $0.82 b^{* *}$ & $9.75 \mathrm{bc}^{* *}$ & $2.70 \mathrm{c}^{* *}$ \\
\hline 5. & Folicur 1.0 $\mathrm{L} \mathrm{ha}^{-1}$ & $0.05 \mathrm{a}$ & $0.00 \mathrm{a}$ & $3.90 \mathrm{~b}^{* *}$ & $2.32 \mathrm{~b}^{*}$ & $13.38 \mathrm{~b}^{* *}$ & $9.30 \mathrm{ab}$ \\
\hline 6. & Opera N $0.8 \mathrm{~L} \mathrm{ha}^{-1}$ & $0.04 \mathrm{a}$ & $0.02 \mathrm{a}$ & $0.42 \mathrm{~d}^{* *}$ & $1.82 b^{* *}$ & $3.28 \mathrm{~d}^{* *}$ & $3.72 \mathrm{c}^{*}$ \\
\hline 7. & Impact $0.25 \mathrm{~L} \mathrm{ha}^{-1} \times 2$ & $0.04 \mathrm{a}$ & $0.12 \mathrm{a}$ & $1.42 \mathrm{~cd}^{* *}$ & $2.14 b^{* *}$ & $3.55 \mathrm{~d}^{* *}$ & $2.98 \mathrm{c}^{* *}$ \\
\hline 8. & Opus $1.0 \mathrm{~L} \mathrm{ha}^{-1} \times 2$ & $0.02 \mathrm{a}$ & $0.06 \mathrm{a}$ & $1.98 \mathrm{bcd}^{* *}$ & $1.15 b^{* *}$ & $1.70 \mathrm{~d}^{* *}$ & $4.18 b^{*}$ \\
\hline 9. & Artea $0.5 \mathrm{~L} \mathrm{ha}^{-1} \times 2$ & $0.03 \mathrm{a}$ & $0.02 \mathrm{a}$ & $2.82 \mathrm{bc} * *$ & $2.98 b^{*}$ & $5.28 \mathrm{~cd}^{* *}$ & $7.65 \mathrm{abc}$ \\
\hline 10. & Folicur 1.0 $\mathrm{L} \mathrm{ha}^{-1} \times 2$ & $0.05 \mathrm{a}$ & $0.21 \mathrm{a}$ & $1.82 \mathrm{c}^{* *}$ & $3.40 \mathrm{ab}$ & $4.95 \mathrm{~cd}^{* *}$ & $7.48 \mathrm{abc}$ \\
\hline 11. & Opera N $0.8 \mathrm{~L} \mathrm{ha}^{-1} \times 2$ & $0.08 \mathrm{a}$ & $0.12 \mathrm{a}$ & $0.77 \mathrm{~d}^{* *}$ & $2.50 b^{*}$ & $3.50 \mathrm{~d}^{* *}$ & $6.68 \mathrm{abc}$ \\
\hline
\end{tabular}

Note. $*$ - significant difference from the control treatment at $95 \%$ probability level, ${ }^{* *}$ - at $99 \%$ probability level; numbers followed by different letters within the same column are significantly different at $p<0.05$. 
Table 4. Biological efficacy (\%) of fungicide application

\begin{tabular}{|c|c|c|c|c|c|}
\hline \multirow{2}{*}{ No. } & \multirow{2}{*}{ Treatments } & \multicolumn{2}{|c|}{2012} & \multicolumn{2}{|c|}{2013} \\
\hline & & cercospora & ramularia & cercospora & ramularia \\
\hline 1. & Untreated (control) & - & - & - & - \\
\hline 2. & Impact $0.4 \mathrm{~L} \mathrm{ha}^{-1}$ & 77.1 & 26.7 & 60.3 & 74.4 \\
\hline 3. & Opus $1.0 \mathrm{~L} \mathrm{ha}^{-1}$ & 87.4 & 96.7 & 46.1 & 62.0 \\
\hline 4. & Artea $0.5 \mathrm{~L} \mathrm{ha}^{-1}$ & 54.3 & 0.0 & 75.3 & 56.0 \\
\hline 5. & Folicur $1.0 \mathrm{~L} \mathrm{ha}^{-1}$ & 37.2 & 73.3 & 15.1 & 66.0 \\
\hline 6. & Opera N $0.8 \mathrm{~L} \mathrm{ha}^{-1}$ & 84.6 & 100.0 & 66.0 & 48.0 \\
\hline 7. & Impact $0.25 \mathrm{~L} \mathrm{ha}^{-1} \times 2$ & 83.3 & 73.3 & 72.8 & 82.0 \\
\hline 8. & Opus $1.0 \mathrm{~L} \mathrm{ha}^{-1} \times 2$ & 92.0 & 93.3 & 61.8 & 75.0 \\
\hline 9. & Artea $0.5 \mathrm{~L} \mathrm{ha}^{-1} \times 2$ & 75.2 & 93.3 & 30.1 & 25.0 \\
\hline 10. & Folicur $1.0 \mathrm{~L} \mathrm{ha}^{-1} \times 2$ & 76.8 & 96.7 & 31.7 & 38.0 \\
\hline 11. & Opera N $0.8 \mathrm{~L} \mathrm{ha}^{-1} \times 2$ & 83.6 & -53.3 & 39.0 & 67.0 \\
\hline
\end{tabular}

assessment), only fungicides Ipact, Opus and Atea (treatments Nos. 2, 3 and 4) caused significant decrease of ramularia severity (Table 5). During the month between the first and the second fungicide application, the severity of ramularia increased nearly 3 times. Analysis of research data showed average correlation between severities at the beginning and the end of the period $(r=0.582)$. After the second application of fungicides (the third assessment), significantly lower severity ramularia leaf spot was observed in the plots treated once with Impact, Folicur and twice with Impact and Opus (treatments Nos. 2, 5, 7 and 8). Generally, the effect of double application of the tested fungicides was not significantly higher than single.

Table 5. Ramularia leaf spot severity (\%) in sugar-beets crops

\begin{tabular}{|c|c|c|c|c|c|}
\hline \multirow[t]{2}{*}{ No. } & \multirow[t]{2}{*}{ Treatments } & \multicolumn{2}{|c|}{$\begin{array}{l}\text { A month after the first fungicide } \\
\text { application }\end{array}$} & \multicolumn{2}{|c|}{$\begin{array}{l}\text { A month after the second fungicide } \\
\text { application }\end{array}$} \\
\hline & & 2012 & 2013 & 2012 & 2013 \\
\hline 1. & Untreated (control) & $0.30 \mathrm{ab}$ & $0.30 \mathrm{a}$ & $1.00 \mathrm{a}$ & $0.10 \mathrm{a}$ \\
\hline 2. & Impact $0.4 \mathrm{~L} \mathrm{ha}^{-1}$ & $0.04 \mathrm{~cd}^{*}$ & $0.22 \mathrm{a}$ & $0.26 b^{*}$ & $0.00 b^{* *}$ \\
\hline 3. & Opus $1.0 \mathrm{~L} \mathrm{ha}^{-1}$ & $0.07 \mathrm{c}^{*}$ & $0.01 \mathrm{a}$ & $0.38 \mathrm{ab}$ & $0.00 b^{* *}$ \\
\hline 4. & Artea $0.5 \mathrm{~L} \mathrm{ha}^{-1}$ & $0.07 \mathrm{c}^{*}$ & $0.30 \mathrm{a}$ & $0.44 \mathrm{ab}$ & $0.01 \mathrm{~b}^{* *}$ \\
\hline 5. & Folicur 1.0 $\mathrm{L} \mathrm{ha}^{-1}$ & $0.25 \mathrm{abc}$ & $0.08 \mathrm{a}$ & $0.34 b^{*}$ & $0.01 b^{* *}$ \\
\hline 6. & Opera N $0.8 \mathrm{~L} \mathrm{ha}^{-1}$ & $0.22 \mathrm{abcd}$ & $0.00 \mathrm{a}$ & $0.52 \mathrm{ab}$ & $0.00 \mathrm{~b}^{* *}$ \\
\hline 7. & Impact $0.25 \mathrm{~L} \mathrm{ha}^{-1} \times 2$ & $0.25 \mathrm{abc}$ & $0.08 \mathrm{a}$ & $0.18 b^{*}$ & $0.00 \mathrm{~b}^{* *}$ \\
\hline 8. & Opus $1.0 \mathrm{~L} \mathrm{ha}^{-1} \times 2$ & $0.12 \mathrm{bcd}$ & $0.02 \mathrm{a}$ & $0.25^{*} \mathrm{~b}$ & $0.01 \mathrm{~b}^{* *}$ \\
\hline 9. & Artea $0.5 \mathrm{~L} \mathrm{ha}^{-1} \times 2$ & $0.42 \mathrm{a}$ & $0.02 \mathrm{a}$ & $0.75 \mathrm{ab}$ & $0.00 b^{* *}$ \\
\hline 10. & Folicur 1.0 $\mathrm{L} \mathrm{ha}^{-1} \times 2$ & $0.30 \mathrm{ab}$ & $0.01 \mathrm{a}$ & $0.62 \mathrm{ab}$ & $0.00 b^{* *}$ \\
\hline 11. & Opera N $0.8 \mathrm{~L} \mathrm{ha}^{-1} \times 2$ & $0.25 \mathrm{abc}$ & $0.46 \mathrm{a}$ & $0.33 \mathrm{~b}^{*}$ & $0.05 \mathrm{ab}$ \\
\hline
\end{tabular}

Note. * - significant difference from the control treatment at $95 \%$ probability level, ${ }^{* *}$ - at $99 \%$ probability level; numbers followed by different letters within the same column are significantly different at $p<0.05$.

In 2013, the second assessment of disease did not evidence any significant difference between treatments. At the time of the third assessment (a month after the second fungicide application), incidence of ramularia leaf spot decreased. Little incidence of ramularia leaf spot was found in untreated and Opera N $0.8 \mathrm{~L} \mathrm{ha}^{-1}$ (treatment No. 11) plots.

In 2012, application of fungicide against ramularia leaf spot was mainly effective (Table 4), except Opera N $0.8 \mathrm{~L} \mathrm{ha}^{-1} \times 2$ and Artea $0.5 \mathrm{~L} \mathrm{ha}^{-1}$ (treatments Nos. 11 and 4) application. Low efficacy showed Impact $0.4 \mathrm{~L}$ ha $^{-1}$ (treatment No. 2). Such efficacy of these treatments could be resulted by the low ramularia severity before the second fungicide application. Efficacy of other fungicide treatments varied from $73.3 \%$ to $100.0 \%$. In 2013 , all of the fungicides were more or less effective (Table 4). Weak efficacy was established by application of Artea $0.5 \mathrm{~L} \mathrm{ha}^{-1} \times 2$, Folicur $1 \mathrm{~L} \mathrm{ha}^{-1} \times 2$ and Opera N $0.8 \mathrm{~L} \mathrm{ha}^{-1}$ (treatments Nos. 9, 10 and 6). The most effective were Impact $0.25 \mathrm{~L} \mathrm{ha}^{-1} \times 2$, Opus $1 \mathrm{~L} \mathrm{ha}^{-1} \times 2$ and Impact 0.4 $\mathrm{L} \mathrm{ha}^{-1}$ (treatments Nos. 7, 8 and 2).

The most stable (during all seasons) high efficacy against ramularia leaf spot was demonstrated by the application of fungicides Opus once and twice (a.i. epoxiconazole) and Impact (a.i. flutriafol) - twice. In Thach et al. (2013) experiments, triazoles and strobilurins (a.i. epoxiconazole, pyraclostrobin, difenoconaloze and its mixtures) were effective for the control of ramularia leaf spot in sugar beet crop.

Powdery mildew. In both years of our experiment, at the time of the first disease assessment (before fungicide application), powdery mildew incidence in sugar beet crop were not found. In 2012, a month after the first spraying with fungicides (the second assessment), all of the treatments had the same significant effect on disease incidence - damaged plants were not found. In 2013, sugar beet crop was free from infestation of powdery mildew, except treatment No. 11 (data are not presented).

In 2012, at the time of the third assessment, the most effective was application of Opus $1.0 \mathrm{~L} \mathrm{ha}^{-1}$ twice (treatment No. 8), but the impact was insignificant compared with the control (Table 6). Double application of fungicides was not more effective than single, except Folicur. In 2013, the second application of fungicides was not effective at all. In all treated plots the severity of powdery mildew was by 1.3-2.9 times higher. This might have been caused by the late emergence of powdery mildew disease and short time for effective impact of fungicides. In Karaoglanidis and Karadimos (2006) experiment, the mixtures of active ingredients (a.i.) azoxystrobin and pyraclostrobin with either 
difenoconazole or cyproconazole showed higher efficacy of powdery mildew control compared to single applications of individual active ingredients. Tank mixtures of trifloxystrobin and kresoxim-methyl with either difenoconazole or cyproconazole provided more efficient control compared to single applications of difenoconazole or cyproconazole.

Table 6. Powdery mildew severity (\%) a month after the second fungicide application

\begin{tabular}{clcc}
\hline No. & \multicolumn{1}{c}{ Treatments } & 2012 & 2013 \\
\hline 1. & Untreated (control) & $4.02 \mathrm{ab}$ & $0.68 \mathrm{~b}$ \\
2. & Impact $0.4 \mathrm{~L} \mathrm{ha}^{-1}$ & $3.38 \mathrm{ab}$ & $1.98 \mathrm{a}^{*}$ \\
3. & Opus $1.0 \mathrm{~L} \mathrm{ha}^{-1}$ & $0.45 \mathrm{ab}$ & $1.88 \mathrm{a}^{*}$ \\
4. & Artea $0.5 \mathrm{~L} \mathrm{ha}^{-1}$ & $3.45 \mathrm{ab}$ & $1.10 \mathrm{ab}$ \\
5. & Folicur $1.0 \mathrm{~L} \mathrm{ha}^{-1}$ & $5.25 \mathrm{a}$ & $1.28 \mathrm{ab}$ \\
6. & Opera N $0.8 \mathrm{~L} \mathrm{ha}^{-1}$ & $2.58 \mathrm{ab}$ & $1.05 \mathrm{ab}$ \\
7. & Impact $0.25 \mathrm{~L} \mathrm{ha}^{-1} \times 2$ & $0.08 \mathrm{~b}$ & $1.44 \mathrm{ab}$ \\
8. & Opus $1.0 \mathrm{~L} \mathrm{ha}^{-1} \times 2$ & $0.00 \mathrm{~b}$ & $0.95 \mathrm{ab}$ \\
9. & Artea $0.5 \mathrm{~L} \mathrm{ha}^{-1} \times 2$ & $0.83 \mathrm{ab}$ & $0.90 \mathrm{ab}$ \\
10. & Folicur $1.0 \mathrm{~L} \mathrm{ha}^{-1} \times 2$ & $0.16 \mathrm{~b}$ & $0.92 \mathrm{ab}$ \\
11. & Opera N $0.8 \mathrm{~L} \mathrm{ha}^{-1} \times 2$ & $0.21 \mathrm{~b}$ & $1.50 \mathrm{ab}$ \\
\hline
\end{tabular}

Note. * - significant difference from the control treatment at 95\% probability level; numbers followed by different letters within the same column are significantly different at $p<0.05$.

Root yield and quality. In our experiment, dry conditions during the periods between August and September restricted severity of diseases. So, application of various fungicides had insignificant and non-regular effect on sugar beet yield and sucrose content in the roots (Table 7). Braziene (2011) has indicated that in the conditions of warm and wet weather, the severity of fungal diseases was high, and fungicides increased yield and sucrose content in the roots by $7.4-14.5 \%$ and $2.2-14.5 \%$.
In our experiment, the treatments Impact $0.4 \mathrm{~L} \mathrm{ha}^{-1}$ and Opera $\mathrm{N} 0.8 \mathrm{~L} \mathrm{ha}^{-1}$ (treatments Nos. 2 and 6) slightly (1.22-3.44 $\left.\mathrm{t} \mathrm{ha}^{-1}\right)$ increased the root yield in 2012. In 2013, treatments Impact $0.4 \mathrm{~L} \mathrm{ha}^{-1}$ (92.93 $\left.\mathrm{t} \mathrm{ha}^{-1}\right)$ and Artea $0.5 \mathrm{~L} \mathrm{ha}^{-1} \times 2\left(91.63 \mathrm{t} \mathrm{ha}^{-1}\right)$ were the most effective. On average, only treatment Impact $0.4 \mathrm{~L} \mathrm{ha}^{-1}$ significantly (by $4.8 \%$ ) increased root yield compared with the control. Thach et al. (2013) found that fungicide compounds (active ingredients) pyraclostrobin, epoxiconazole, difenoconazole and propiconazole gave effective control against ramularia. Positive net yield responses (on average 0.7-2.2 $\mathrm{t} \mathrm{ha}^{-1}$ ) were found in 9 out of 11 seasons. In our experiment, the severity of ramularia leaf spot had impact on yield $\left(r=-0.752^{* *}\right)$, sucrose content $\left(r=-0.725^{* *}\right)$, content of potassium and alpha amino nitrogen $\left(r=-0.626^{* *}\right.$ and $-0.642 * *)$ in the sugar beet roots. In USA, Khan and Smith (2005) established that a.i. pyraclostrobin caused increase of sugar beet root yield and sugar yield by 20 and $3.059 \mathrm{t} \mathrm{ha}^{-1}$. In Gado (2007) experiment, reduction of cercospora leaf spot severity increased sugar beet root weight and sugar content, and decreased impurities, i.e. sodium, potassium and alpha amino acid contents. The correlation analysis of experimental results showed weak relation between severity of cercospora, powdery mildew and yield-quality of roots.

In our experiment, in 2012, the highest sucrose content was determined in the sugar beet roots grown in the plots treated with Artea $0.5 \mathrm{~L} \mathrm{ha}^{-1} \times 2(18.08 \%)$ and Folicur $1.0 \mathrm{~L} \mathrm{ha}^{-1} \times 2(18.05 \%)$. In 2013, treatments Artea $0.5 \mathrm{~L} \mathrm{ha}^{-1}$ and Opera $\mathrm{N} 0.8 \mathrm{~L} \mathrm{ha}^{-1}$ were more effective. On average, treatment Artea $0.5 \mathrm{~L} \mathrm{ha}^{-1}$ (treatment No. 4) increased sucrose content in the roots by the $2.46 \%$. Generally, double application of fungicides had essentially the same and insignificant impact on sucrose content in the roots as single. In 2012, only single application of the

Table 7. Effect of different fungicides on sugar beet yield and quality of roots

\begin{tabular}{|c|c|c|c|c|c|c|}
\hline No. & Treatments & $\begin{array}{c}\text { Root yield } \\
\mathrm{t} \mathrm{ha}^{-1}\end{array}$ & $\begin{array}{c}\text { Sucrose } \\
\%\end{array}$ & $\begin{array}{l}\text { Potassium } \\
\text { mmol } 100 \mathrm{~g}^{-1}\end{array}$ & $\begin{array}{c}\text { Sodium } \\
\text { mmol } 100 \mathrm{~g}^{-1}\end{array}$ & 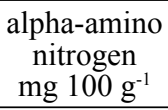 \\
\hline \multicolumn{7}{|c|}{2012} \\
\hline 1. & Untreated (control) & $79.87 \mathrm{ab}$ & $17.68 \mathrm{a}$ & $3.95 \mathrm{a}$ & $0.35 \mathrm{a}$ & $12.5 \mathrm{a}$ \\
\hline 2. & Impact $0.4 \mathrm{~L} \mathrm{ha}^{-1}$ & $83.31 \mathrm{a}$ & $17.78 \mathrm{a}$ & $3.67 \mathrm{ab}$ & $0.31 \mathrm{ab}$ & $9.6 \mathrm{ab}$ \\
\hline 3 . & Opus $1.0 \mathrm{~L} \mathrm{ha}^{-1}$ & $79.59 \mathrm{ab}$ & $17.62 \mathrm{a}$ & $3.63 \mathrm{ab}$ & $0.28 \mathrm{ab}$ & $9.6 \mathrm{ab}$ \\
\hline 4. & Artea $0.5 \mathrm{~L} \mathrm{ha}^{-1}$ & $78.22 \mathrm{ab}$ & $17.93 \mathrm{a}$ & $3.40 b^{*}$ & $0.25 \mathrm{ab}^{*}$ & $8.8 \mathrm{ab}$ \\
\hline 5. & Folicur $1.0 \mathrm{~L} \mathrm{ha}^{-1}$ & $77.78 \mathrm{ab}$ & $17.78 \mathrm{a}$ & $3.51 b^{*}$ & $0.32 \mathrm{ab}$ & $9.9 \mathrm{ab}$ \\
\hline 6. & Opera N $0.8 \mathrm{~L} \mathrm{ha}^{-1}$ & $81.09 \mathrm{ab}$ & $17.71 \mathrm{a}$ & $3.76 \mathrm{ab}$ & $0.28 \mathrm{ab}$ & $8.6 \mathrm{ab}$ \\
\hline 7. & Impact $0.25 \mathrm{~L} \mathrm{ha}^{-1} \times 2$ & $78.82 \mathrm{ab}$ & $17.78 \mathrm{a}$ & $3.72 \mathrm{ab}$ & $0.35 \mathrm{a}$ & $8.7 \mathrm{ab}$ \\
\hline 8. & Opus $1.0 \mathrm{~L} \mathrm{ha}^{-1} \times 2$ & $79.97 \mathrm{ab}$ & $17.92 \mathrm{a}$ & $3.41 \mathrm{~b}^{*}$ & $0.31 \mathrm{ab}$ & $7.6 b^{*}$ \\
\hline 9. & Artea $0.5 \mathrm{~L} \mathrm{ha}^{-1} \times 2$ & $78.54 \mathrm{ab}$ & $18.08 \mathrm{a}$ & $3.60 \mathrm{ab}$ & $0.27 \mathrm{ab}$ & $7.5 b^{*}$ \\
\hline 10. & Folicur $1.0 \mathrm{~L} \mathrm{ha}^{-1} \times 2$ & $79.26 \mathrm{ab}$ & $18.05 \mathrm{a}$ & $3.42 b^{*}$ & $0.23 \mathrm{~b}^{*}$ & $8.7 \mathrm{ab}$ \\
\hline 11. & Opera N $0.8 \mathrm{~L} \mathrm{ha}^{-1} \times 2$ & $77.15 \mathrm{~b}$ & $17.75 \mathrm{a}$ & $3.70 \mathrm{ab}$ & $0.32 \mathrm{ab}$ & $10.0 \mathrm{ab}$ \\
\hline \multicolumn{7}{|c|}{2013} \\
\hline 1. & Untreated (control) & $88.28 \mathrm{a}$ & $18.54 \mathrm{ab}$ & $4.25 \mathrm{a}$ & $0.32 \mathrm{ab}$ & $16.4 \mathrm{ab}$ \\
\hline 2. & Impact $0.4 \mathrm{~L} \mathrm{ha}^{-1}$ & $92.93 \mathrm{a}$ & $18.80 \mathrm{ab}$ & $4.18 \mathrm{a}$ & $0.25 \mathrm{~b}$ & $13.8 \mathrm{~b}$ \\
\hline 3. & Opus $1.0 \mathrm{~L} \mathrm{ha}^{-1}$ & $86.72 \mathrm{a}$ & $18.57 \mathrm{ab}$ & $4.11 \mathrm{a}$ & $0.37 \mathrm{ab}$ & $18.8 \mathrm{ab}$ \\
\hline 4. & Artea $0.5 \mathrm{~L} \mathrm{ha}^{-1}$ & $90.32 \mathrm{a}$ & $19.18 \mathrm{a}$ & $4.07 \mathrm{a}$ & $0.22 \mathrm{~b}$ & $15.4 \mathrm{~b}$ \\
\hline 5. & Folicur $1.0 \mathrm{~L} \mathrm{ha}^{-1}$ & $87.13 \mathrm{a}$ & $18.77 \mathrm{ab}$ & $4.14 \mathrm{a}$ & $0.28 \mathrm{ab}$ & $15.7 \mathrm{~b}$ \\
\hline 6. & Opera N $0.8 \mathrm{~L} \mathrm{ha}^{-1}$ & $86.39 \mathrm{a}$ & $18.90 \mathrm{ab}$ & $4.12 \mathrm{a}$ & $0.26 \mathrm{~b}$ & $15.4 \mathrm{~b}$ \\
\hline 7. & Impact $0.25 \mathrm{~L} \mathrm{ha}^{-1} \times 2$ & $89.98 \mathrm{a}$ & $18.66 \mathrm{ab}$ & $4.02 \mathrm{a}$ & $0.22 \mathrm{~b}$ & $13.0 \mathrm{~b}$ \\
\hline 8. & Opus $1.0 \mathrm{~L} \mathrm{ha}^{-1} \times 2$ & $90.26 \mathrm{a}$ & $18.85 \mathrm{ab}$ & $4.12 \mathrm{a}$ & $0.23 \mathrm{~b}$ & $15.8 \mathrm{ab}$ \\
\hline 9. & Artea $0.5 \mathrm{~L} \mathrm{ha}^{-1} \times 2$ & $91.63 \mathrm{a}$ & $18.30 \mathrm{~b}$ & $4.26 \mathrm{a}$ & $0.46 \mathrm{a}$ & $22.6 \mathrm{a}$ \\
\hline 10. & Folicur $1.0 \mathrm{~L} \mathrm{ha}^{-1} \times 2$ & $87.80 \mathrm{a}$ & $18.77 \mathrm{ab}$ & $4.19 \mathrm{a}$ & $0.24 \mathrm{~b}$ & $15.5 \mathrm{~b}$ \\
\hline 11. & Opera N $0.8 \mathrm{~L} \mathrm{ha}^{-1} \times 2$ & $86.02 \mathrm{a}$ & $18.52 \mathrm{ab}$ & $4.14 \mathrm{a}$ & $0.35 \mathrm{ab}$ & $16.4 \mathrm{ab}$ \\
\hline
\end{tabular}

Note. ${ }^{*}$ - significant difference from the control treatment at $95 \%$ probability level; numbers followed by different letters within the same column are significantly different at $p<0.05$. 
fungicides Artea, Folicur and double application of Opus and Folicur (treatments Nos. 4, 5, 8, 10) significantly decreased potassium content in sugar beet roots compared with the control (Table 7). The differences between single and double application of fungicides were insignificant. In 2013, significant differences between all the treatments were not found. The correlation analysis showed weak tendencies of diseases impact on potassium increase in the roots.

Only in 2012 treatments Artea $0.5 \mathrm{~L} \mathrm{ha}^{-1}$ and Folicur $1.0 \mathrm{~L} \mathrm{ha}^{-1} \times 2$ significantly decreased the amount of sodium in the roots compared with the control.

In 2012, all the tested fungicides decreased the content of alpha amino nitrogen in the roots; however only double application of fungicides Opus and Artea (treatments Nos. 8 and 9) had significant effect compared with the control. Differences between other treatments were insignificant. In 2013, the impact of fungicide treatments was insignificant compared with the untreated control.

\section{Conclusions}

1. The most widespread fungal disease in sugar beet crop was Cercospora beticola. The severity of Ramularia beticola and Erysiphe betae was on average about 15 and 8 times lower than that of Cercospora beticola.

2. Application of fungicides significantly decreased the severity of cercospora and ramularia leaf spots at the end of sugar beet growing season by on average $19.8-81.8 \%$ and $71.8-91.8 \%$. Treatments Opus 1.0 $\mathrm{L} \mathrm{ha}^{-1}$, Opus $1.0 \mathrm{~L} \mathrm{ha}^{-1} \times 2$ (a.i. epoxiconazole) and Impact $0.4 \mathrm{~L} \mathrm{ha}^{-1}$ (a.i. flutriafol) were the most effective against leaf spots. A double application of the tested fungicides had no significant effect on the severity of leaf spots compared with a single application.

3 . The severity of powdery mildew during the experimental years was low; therefore, the efficacy of various fungicides was mainly insignificant. The most effective was treatment Opus $1.0 \mathrm{~L} \mathrm{ha}^{-1} \times 2$.

4. Application of various active ingredients of fungicides had insignificant effect on sugar beet yield and sucrose content in the roots. A single application of fungicide Artea $0.5 \mathrm{~L} \mathrm{ha}^{-1}$ (a.i. propiconazole + cyproconazole) and a double application of Opus 1.0 $\mathrm{L} \mathrm{ha}{ }^{-1}$ (a.i. epoxiconazole) and Folicur 1.0 L ha' (a.i. tebuconazole) significantly decreased the content of impurities (potassium, sodium, alpha amino nitrogen) in the sugar beet roots compared with the untreated control.

\section{Acknowledgements}

The study was supported by the joint-stock company "Nordic Sugar Kèdainiai" and agricultural cooperative "Kèdainiu krašto cukriniai runkeliai".

Received 23102015

Accepted 17032016

\section{References}

Asher M. J. C., Hanson L. E. 2006. Fungal and bacterial diseases. Draycot A. P. (ed.). Sugar beet. Oxford, UK, p. $286-315$

http://dx.doi.org/10.1002/9780470751114.ch12

Baltaduonytė M., Dabkevičius Z. 2015. The occurrence of leaf spotting diseases in different sugar beet varieties. Žemès ūkio mokslai, 22 (1): 8-14
Baltaduonytė M., Dabkevičius Z., Brazienė Z., Survilienė E. 2013. Dynamics of spread and control of cercospora (Cercospora beticola Sacc.) and ramularia (Ramularia beticola Fautrey \& F.Lamb.) leaf spot in sugar beet crops. Zemdirbyste-Agriculture, 100 (4): 401-408 http://dx.doi.org/10.13080/z-a.2013.100.051

Brazienè Z. 2011. The effect of fungal diseases and harvesting timing on sugar-beet productivity. Žemès ūkio mokslai, $18(2): 47-52$

Compendium of beet diseases and insects. 1986. Whitney E. D., Duffus J. E. (eds.). The American Phytopathological Society, St. Paul, USA

EPPO Standards. 2004. Efficacy Evaluation of Fungicides and Bactericides, vol. 2

Deveikytė I., Petkevičienė B., Kaunas J. 2009. Sugar beet: agrobiology, research, technologies (in Lithuanian)

Duffus J. E., Ruppel E. G. 1993. Disseases. Cooke D. A., Scott R. K. (eds.). The sugar beet crop. Science into practice, p. 346-411

Francis S. 2002. Sugar beet powdery mildew (Erysiphe betae). Molecular Plant Technology, 3 (3): 119-124 http://dx.doi.org/10.1046/j.1364-3703.2002.00103.x

Gado E. A. M. 2007. Management of cercospora leaf spot disease of sugar beet plants by some fungicides and plant extracts. Egyptian Journal of Phytopathology, 35 (2): 1-10

Gaurilčikienè I., Deveikyte I., Petraitienė E. 2006. Epidemic progress of Cercospora beticola Sacc. Beta vulgaris $\mathrm{L}$. under different conditions and cultivar resistance. Biologija, 4: 54-59

Gummert A., Ladewig E., Bürcky K., Märländer B. 2015. Variety resistance to Cercospora leaf spot and fungicide application as tools of integrated pest management in sugar beet cultivation - a German case study. Crop Protection, 72: $182-194$ http://dx.doi.org/10.1016/j.cropro.2015.02.024

Hanse B., Schneider J. H. M., Termorshuizen A. J., Varrelmann M. 2011. Pests and diseases contribute to sugar beet yield difference between top and averagely managed farms. Crop Protection, 30: 671-678 http://dx.doi.org/10.1016/j.cropro.2011.02.018

Hoffmann C. M., Huijbregts T., van Swaaij N., Jansen R. 2009. European Journal of Agronomy, 30: 17-26 http://dx.doi.org/10.1016/j.eja.2008.06.004

Karaoglanidis G. S., Karadimos D. A. 2006. Efficacy of strobilurins and mixtures with DMI fungicides in controlling powdery mildew in field-grown sugar beet. Crop Protection, 25: 977-983 http://dx.doi.org/10.1016/j.cropro.2006.01.005

Khan F. R., Smith L. J. 2005. Evaluating fungicides for controlling Cercospora leaf spot on sugar beet. Crop Protection, 24: 79-86 http://dx.doi.org/10.1016/j.cropro.2004.06.010

Khan M. F. R. 2015. Sugar beet diseases: Cercospora leaf spot. Ishii H., Hollomon D. W. (eds.). Fungicide resistance in plant pathogens: principles and guide to practicals management, p. 379-387

Märländer B., Hoffmann C., Koch H. J., Ladewig E., Merkes R., Petersen J., N. Stockfisch. 2003. Environmental situation and yield performance of the sugar beet crop in Germany: heading for sustainable development. Journal of Agronomy and Crop Science, 189: 201-226 http://dx.doi.org/10.1046/j.1439-037X.2003.00035.x

Petkevičienè B., Kaunas J. 2004. Influence of natural conditions on the prevalence of cercospora leaf spot (Cercospora beticola Sacc.) and ramularia leaf spot (Ramularia beticola Fant \& Lamb.) in different varieties of sugar beet. Žemès ūkio mokslai, 4: 28-35 
Piszczek J. 2001. Influence of crop rotation on infection of sugar beet by Cercospora beticola. Progress in Plant Protection, 41 (2): 650-653

Secor G. A., Rivera V. V., Khan M. F. R., Gudmestad N. C. 2010. Monitoring fungicide sensitivity of Cercospora beticola of sugar beet for disease management decisions. Plant Disease, 94 (11): 1272-1282 http://dx.doi.org/10.1094/PDIS-07-09-0471

Thach T., Munk L., Hansen A. L., Jørgensen L. N. 2013. Disease variation and chemical control of Ramularia leaf spot in sugar. Crop Protection, 51: 68-76 http://dx.doi.org/10.1016/j.cropro.2013.04.010

Trkulja N., Milosavljević A., Stanisavljević R., Mitrović M., Jović J., Tosevski I., Bosković J. 2015. Occurrence of Cercospora beticola populations resistant to benzimidazoles and demethylation-inhibiting fungicides in Serbia and their impact on disease management. Crop Protection, 75: 80-87

http://dx.doi.org/10.1016/j.cropro.2015.05.017
Vereijssen J., Schneider J. H. M., Termorshuizen A. J., Jeger M. J. 2003. Comparison of two disease assessment methods for assessing Cercospora leaf spot in sugar beet. Crop Protection, 22: 201-209

http://dx.doi.org/10.1016/S0261-2194(02)00146-1

Vereijssen J., Schneider J. H. M., Jeger M. J. 2007. Supervised control of Cercospora leaf spot in sugar beet. Crop Protection, 26: 19-28 http://dx.doi.org/10.1016/j.cropro.2006.03.012

Weiland J., Koch G. 2004. Sugar beet leaf spot disease (Cercospora beticola Sacc.). Molecular Plant Pathology, 5 (3): 157-166 http://dx.doi.org/10.1111/j.1364-3703.2004.00218.x

WRB, 2014. World reference base for soil resources 2014 . International soil classification system for naming soils and creating legends for soil maps. World Soil Resources Reports No. 106. FAO, Rome

Žemès ūkio augalų kenkejjai, ligos ir jų apskaita. 2002 / compiled by Šurkus J., Gaurilčikienè I. Lithuanian Institute of Agriculture, 345 p. (in Lithuanian)

ISSN 1392-3196 / e-ISSN 2335-8947

Zemdirbyste-Agriculture, vol. 103, No. 2 (2016), p. 167-174

DOI 10.13080/z-a.2016.103.022

\title{
Fungicidų efektyvumas cukrinių runkelių pasėliuose
}

\author{
D. Avižienyte் ${ }^{1}, Z$. Brazienè ${ }^{1}$, K. Romaneckas ${ }^{2,3}$, A. Marcinkevičius ${ }^{1}$ \\ ${ }^{1}$ Lietuvos agrarinių ir miškų mokslų centro Rumokų bandymų stotis \\ ${ }^{2}$ Aleksandro Stulginskio universitetas \\ ${ }^{3}$ Kauno miškų ir aplinkos inžinerijos kolegija
}

\section{Santrauka}

Rudmargè ir baltuliai yra žalingiausios cukrinių runkelių ligos Europoje. Tyrimų tikslas - j̨vertinti grybinių ligų intensyvumą ir ịvairių naujausių fungicidų bei jų dozių efektyvumą cukrinių runkelių pasèliuose Lietuvoje. Trumpalaikis lauko eksperimentas buvo atliktas 2012 ir 2013 m. LAMMC Rumokų bandymų stotyje. Eksperimento dirvožemis - paprastojo išplautžemio (IDg8-p) vidutinio sunkumo priemolis. Fungicidai Impact (v. m. flutriafolas), Opus (v. m. epoksikonazolas), Artea (v. m. propikonazolas + ciprokonazolas), Folicur (v. m. tebukonazolas), Opera N (v. m. piraklostrobinas + epoksikonazolas) buvo purkšti vieną kartą - cukrinių runkelių lapų ligų plitimo pradžioje (rugpjūtị), ir du kartus - cukrinių runkelių lapų ligų plitimo pradžioje (rugpjūtị) ir praejjus mènesiui (rugsèji). Tyrimų duomenimis, cukrinių runkelių pasèliuose labiausiai plito grybinès ligos rudmargè (Cercospora beticola) ir baltuliai (Ramularia beticola), mažiau - miltligė (Erysiphe betae). Fungicidų išpurškimas 19,8-81,8 ir 71,891,8 proc. sumažino rudmargès ir baltulių pasireiškimo intensyvumą. Efektyviausi nuo rudmargès ir baltulių buvo fungicidai Opus ir Impact. Pakartotinis visų tirtų fungicidų išpurškimas dažniausiai nebuvo pranašesnis už vienkartinị. Efektyviausias nuo miltligès buvo fungicidas Opus, išpurkštas du kartus.

Ivairių fungicidų veikliosios medžiagos dažniausiai netureejo esminės itakos cukrinių runkelių šakniavaisių derlingumui ir cukringumui. Vienkartinis fungicido Artea $0,51 \mathrm{ha}^{-1}$ išpurškimas ir fungicidų Opus $1,01 \mathrm{ha}^{-1}$ bei Folicur 1,0 1 ha $^{-1}$ išpurškimas du kartus iš esmès sumažino priemaišų (kalio, natrio, alfa-amino azoto) kiekị cukrinių runkelių šakniavaisiuose, palyginus su nepurkštais laukeliais.

Reikšminiai žodžiai: Beta vulgaris, Cercospora beticola, derlius, Erysiphe betae, kokybè, Ramularia beticola.

Please use the following format when citing the article:

D. Avižienytė, Z. Brazienè, K. Romaneckas, A. Marcinkevičius. 2016. Efficacy of fungicides in sugar beet crops. Zemdirbyste-Agriculture, 103 (2): 167-174 DOI 10.13080/z-a.2016.103.022 